\title{
A clinical study of the medical condition of patients requiring tooth extraction in Mosul City
}

\author{
Mohammad S SULEIMAN*
}

\begin{abstract}
The number of medically compromised patients is increasing in both dental school patient populations and private practices presenting specific challenges to the dental profession. In this clinical study, the population studied consisted of (2943) patients, of them (1737) were males and (1206) females. The patients selected for this study were those attending Department of oral and maxillo - facial surgery in Saddam Dental Hospital, College of Dentistry, University of Mosul, and the author's private clinic between (1-10-2001 and 1-6-2002). The results showed that about the fifth of the patients (19.06\%) were medically compromised patients (MCP) who need special care during tooth extraction. Lower and upper first molars showed the highest number of tooth extraction (28.94\%). Dental caries and its sequalae were the most common cause of tooth extraction. The age group (15-34 year) contained the highest percentage of tooth loss $(49.13 \%)$
\end{abstract}

Key Worls: compromised patients, tooth extraction, Dental caries

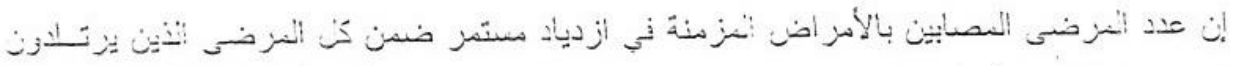

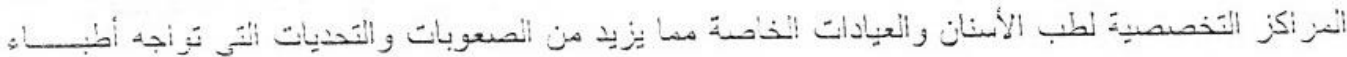

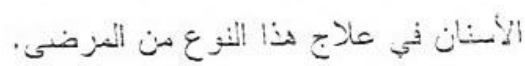

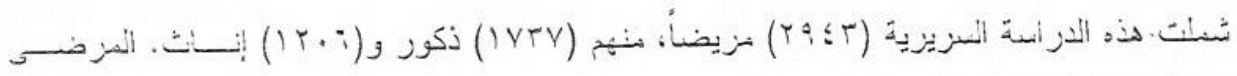

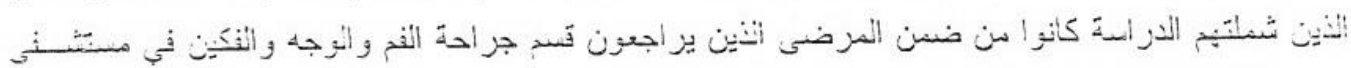

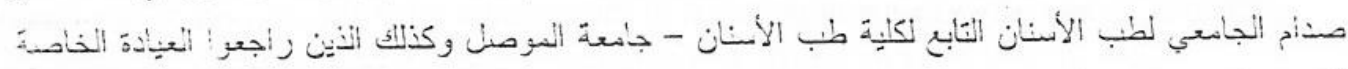

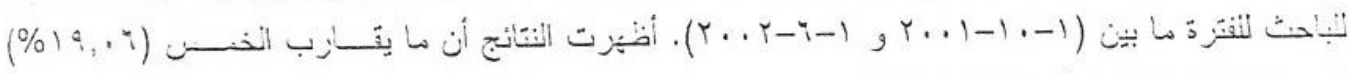

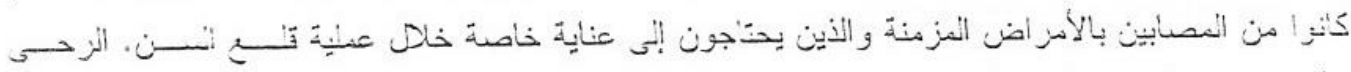

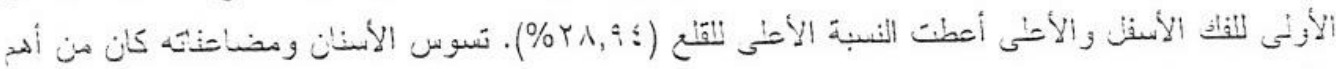

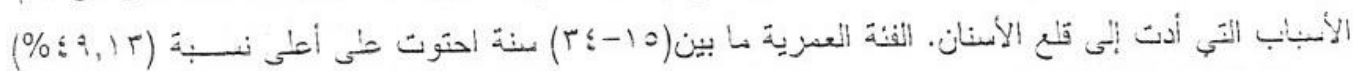

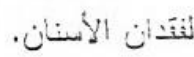

\section{INTRODLCTION}

Tooth loss is a common phenomenon in all of the world ${ }^{(1)}$. Extraction of tooth is a terminal event in the life of a tooth and is a frequent episode in individuals with un-cared and neglected oral cavity ${ }^{(2)}$. It is generally accepted that the number of teeth decreases with age and that caries and periodontal disease are the main causes of tooth loss, although the relative impact of these two disease entities may vary in different population groups and geographic areas ${ }^{(3.4)}$.

*Mohammad Saleh SULEIMAN; BDS, MSc: Assistant Lecturer. Department of Oral and Maxillofacial Surgery, College of Dentistry, University of Mosul. Mosul, IRAQ. 
Because of the increasing numbers of dental patients with chronic medical problems, it is critical that the dentist remains knowledgeable about patient's medical conditions because many disorders will dictate alterations in the provision of dental treatment. Failure to make appropriate treatment modifications may result in serious consequences ${ }^{(5,6)}$. The dentist no longer treats "leeth in-patients" but "patients who have tecth". It is now most important for the safety of the patient and the suceess of treatment for the dentist to identify patients with systemic illness ${ }^{(7)}$.

The aim of the present study was to assess the followings:

(1) Number of MCP out the total number of patients recuiring tooth removal.

(2) The incidence of each systemic discase.

(3) Etiology of tooth extraction and tooth type with the highest incidence of extraction.

\section{MATERIALS AND METHODS}

The study was implemented in oral and Maxillofacial Surgery Department in Saddam Dental Hospital, College of Dentistry, University of Mosul, and in the researcher's private clinic between (1-10-2001 and 1-6-2002). Two thousands nine hundreds and forty three patients were examined, each patient has his (her) own case sheet which contains the following information, the patient name, age, sex, profession, address, Tel. No., chief complaint (c.c.), History of present illness (H.P.I), past dental history (P.D.II), Medical history (M.H), clinical examination, investigations, diagnosis, and treatment plan.

The case sheet which is used in the Department of oral and Maxillofacial Surgery, University of Mosul, College of Dentistry:

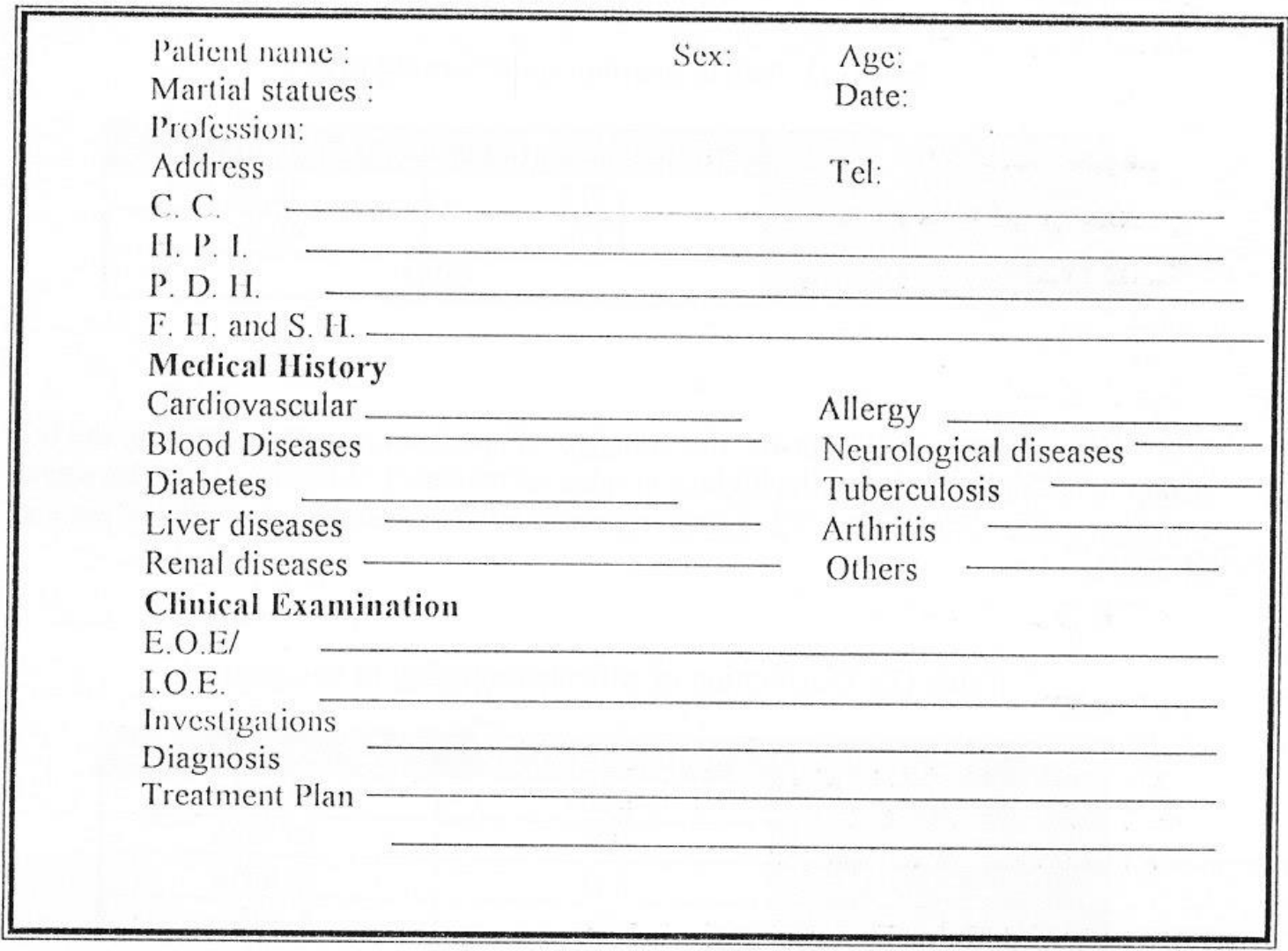


Patients were divided into four groups according to age:

First group: $\Lambda$ ge range from $(15-34)$ year.

Second group: Age range from $(35-54)$ year.

Third group: Age range from $(55-74)$ year.

Fourth group: More than (75) year.

Patients below the age of (15) years, and those with uncontrolled systemic diseases were excluded from the study. The causes for tooth extraction were recorded according to the following criteria:

(1) Teeth with pulpitis that can not be restored by operative dentistry or endodontics.

(2) Devitalized tooth not amenable to root canal therapy.

(3) Periodontal disease beyond treatment.

(4) Impacted or partially erupted teeth with pericoronitis.

(5) Prosthetic indications (i.e. isolated, tilted, hyperocclusion teeth).

(6) Orthodontic indications.

(7) Malposed teeth.

(8) Supernumcrary teeth.

(9) Retained deciduous teeth.

\section{RESULTS}

The patients included in the present study were (2943). Table (1) shows the sex distribution among the examined patients. Number of males was [1737 (59.02\%)], and females [1206 (40.98)], the male to female ratio was (1.44:1).

Table (1): Patient distribution according to sex

\begin{tabular}{|c|c|c|}
\hline Sex & Number of litients & Porcentage \\
\hline Malc & 1737 & 59.02 \\
\hline reunilo : & 1206 & 10.98 \\
\hline Totul No, of patients & \multicolumn{2}{|c|}{2943} \\
\hline
\end{tabular}

The second table shows the number of patients in each age group, the first group (15-34) year shows the highest number of patients [1446 (49.13\%)]. However, the age group (more than 75 years) represented the least number (36) of patients $(1.22 \%)$.

Table (2): Distribution of patients according to age group

\begin{tabular}{|c|c|c|}
\hline Agr igroul & Number of Pitients & Percentager. \\
\hline 15.34 & 1446 & $49.13 \%$ \\
\hline 35. 54 & 906 & $30.78 \%$ \\
\hline $55 .: 15$ & 555 & $18.85 \%$ \\
\hline More Thin 78 & 36 & $1.22 \%$ \\
\hline
\end{tabular}


The number and percentage of patients with and without systemic diseases is shown in table (3). Patients without systemic diseases were [2382 (80.93\%)] with (1440) males (48.92\%) and (942) females (32.01\%), while patients with systemic diseases were [561 (19.06\%)], among them (297) males (10.09\%) and [264 (8.97\%)] females.

Table (3): Medical condition of patients

\begin{tabular}{|c|c|c|c|c|c|}
\hline \multicolumn{3}{|c|}{ 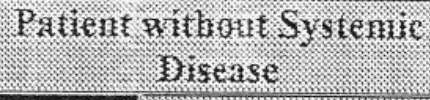 } & \multicolumn{3}{|c|}{$\begin{array}{l}\text { Paternt Pithi Systenic } \\
\text { Disease }\end{array}$} \\
\hline & $\mathrm{x}_{10}$ & $\%$ & 3. & 1. & . 6 \\
\hline 11, It & 1440 & 48.92 & XI:1, & 297 & 10.09 \\
\hline Feminale & 942 & 32.01 & Fenzalle & 264 & 8.97 \\
\hline 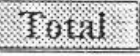 & 2382 & 80.93 & Totat: & 561 & 19.06 \\
\hline
\end{tabular}

Table (4) shows the number and the percentage of the medical problems seen, the cardio- vascular diseases were the highest in number $(294)$ patients $(52.4 \%)$ of the MCP, the Diabetic patients [117 (20.85\%)] followed by Allergy (42) patients $(7.48 \%)$ of all MCP. However, (36) of the MCP had a history of bleeding disease (6.41\%). Renal disease and arthritics showed equal number of patients, (24) patients for each $(4.28 \%)$. The least number was shown in other diseases like hypothyroidism, pregnancy, Migraine, etc...).

Table (4): Number and percentage of the medical problems seen in dental clinic

\begin{tabular}{|c|c|c|c|c|c|c|}
\hline Type of dissezse & $\begin{array}{l}\text { Thanber of } \\
\text { Patrents }\end{array}$ & $18: 3$ & Hale & $8 \%$ & fremiale & 3). \\
\hline Carteto V ascitititir & 294 & 52.4 & 141 & 25.13 & 153 & 27.27 \\
\hline Dinetes & 117 & 20.85 & 75 & 13.36 & 42 & 7.48 \\
\hline : Allergy & 42 & 7.48 & 24 & 4.28 & 18 & 3.20 \\
\hline Bhyod: insease & 36 & 6.41 & 24 & 4.28 & 12 & 2.14 \\
\hline 1,enal & 24 & 4.28 & 12 & 2.14 & 12 & 2.14 \\
\hline Antllyitis & 24 & 4.28 & 10 & 1.78 & 14 & 2.49 \\
\hline Others & 24 & 4.28 & 9 & 1.60 & 15 & 2.67 \\
\hline Iotal & 561 & & 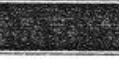 & & & 28 \\
\hline
\end{tabular}

Distribution of MCP according to the age group was shown in table (5), were the highest age group suffering from cardiovascular diseases was the third group (5574 year) then the second group (35-54 year). While in diabetic and allergic patients, the second age group (35-54 years) shows the highest number of patients. The least number was noticed in the fourth group ( 75 year and more) in all age groups except cardiovascular and diabetic patients were the least numbers were noticed in the first group (15-34 years). 
Al-Rafidain Dent J A clinical study of the medical condition of patients... Vol. 2. Sp Iss.. 2002

Table (5): Distribution of medically compromised patients according to age group

\begin{tabular}{|c|c|c|c|c|c|c|c|c|c|}
\hline Type of Diseisse & $\begin{array}{l}15-34 \\
y e x t s\end{array}$ & $8 ;$ & yetrs & 8.6 & $\begin{array}{l}55-74 \\
\text { Yezas }\end{array}$ & (1) & $\begin{array}{c}\text { Thore T:arn } \\
75 \text { lears }\end{array}$ & 8 & Tiotet: \\
\hline 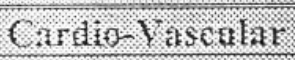 & 9 & 3.06 & 90 & 30.6 & 168 & 57.14 & 27 & 9.18 & 294 \\
\hline Diabetes & 6 & 5.12 & 63 & 53.84 & 39 & 33.33 & 9 & 7.69 & 117 \\
\hline 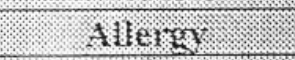 & 9 & 21.42 & 18 & 42.85 & 15 & 35.71 & 0 & 0 & 42 \\
\hline Bleodi itserise & 18 & 50 & 6 & 16.67 & 12 & 33.33 & 0 & 0 & 36 \\
\hline Rerizfi: & 3 & 12.5 & 12 & 50 & 9 & 37.5 & 0 & 0 & 24 \\
\hline If f therititis & 0 & 0 & 9 & 37.5 & 15 & 62.5 & 0 & 0 & 24 \\
\hline Othiers & 18 & 75.0 & 0 & 0 & 6 & 25 & 0 & 0 & 24 \\
\hline
\end{tabular}

Table (6) shows the number and percentage of extracted teeth related to tooth type with a total number of (2943) teeth, those extracted in the upper jaw were (1617) teeth against (1326) teeth extracted in the lower jaw. Lower first molars showed the highest number (456 teeth) of tooth loss (15.49\%), followed by upper first molars 396 teeth $(13.45 \%)$, then upper first premolars $(333)$ teeth $(11.3 \%)$, then lower third molars (234) teeth $(7.94 \%)$ of the total teeth loss. However, the least number (69 teeth) was shown in lower central incisors $(2.34 \%)$.

Table (6): Number of extracted teeth and $\%$ of tooth loss related to tooth type

\begin{tabular}{|c|c|c|c|c|c|c|c|}
\hline & \multirow[b]{2}{*}{ 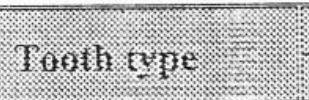 } & \multicolumn{6}{|c|}{ Niminber of Exrurateted Teeth: } \\
\hline & & Righa: & c. & l.eft: & 15: & 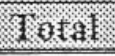 & $\%$ \\
\hline \multirow{8}{*}{$\frac{3}{2}$} & (2. entra) lacisor) & 75 & 2.54 & 54 & 1.83 & 129 & 4.37 \\
\hline & Iraterat Incésor & 48 & 1.63 & 36 & 1.22 & 84 & 2.85 \\
\hline & Canine : & 81 & 2.75 & 87 & 2.95 & 168 & 5.7 \\
\hline & $i^{\prime \prime}$ Prentuluas & 153 & 5.19 & 180 & 6.11 & 333 & 11.3 \\
\hline & 2 in Prementats & 93 & 3.16 & 102 & 3.46 & 195 & 6.62 \\
\hline & fit loger: & 210 & 7.13 & 186 & 6.32 & 396 & 13.45 \\
\hline & $2^{\text {int }}, 1$ iotar & 69 & 2.34 & 84 & 2.85 & 153 & 5.19 \\
\hline & 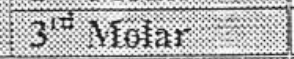 & 84 & 2.85 & 75 & 2.54 & 159 & 5.39 \\
\hline \multirow{8}{*}{$\frac{2}{3}$} & (C. centra) lakison) & 36 & 1.22 & 33 & 1.12 & 69 & 2.34 \\
\hline & I Latera! Incésor & 48 & 1.63 & 30 & 1.02 & 78 & 2.65 \\
\hline & Canine & 57 & 1.93 & 48 & 1.63 & 105 & 3.56 \\
\hline & 1 Premolas & 63 & 2.14 & 75 & 2.54 & 138 & 4.68 \\
\hline & $2^{2}$ Prentivulas & 63 & 2.14 & 48 & 1.63 & 111 & 3.77 \\
\hline & ist Mlotar & 231 & 7.85 & 225 & 7.64 & 456 & 15.49 \\
\hline & $2^{\text {rif }}$ MIolar & 66 & 2.24 & 69 & 2.34 & 135 & 4.58 \\
\hline & $3^{\text {it }}$ VIatar & 81 & 2.75 & 153 & 5.19 & 234 & 7.94 \\
\hline
\end{tabular}


of elastic lamina, both in the gingiva and periodontal membrane, this will interfere with the local blood circulation and causing periodontal disease and loss of tooth ${ }^{(1)}$. This result had also been recorded by other studies $(7,22-27,35)$.

Diabetes mellitus also recorded high number of patient, this could be attributed to the fact that elevated glucose levels, impaired leukocytic function, altered collegen metabolism, and vascular changes including stasis in the microculation can reduce the resistance to periodontal infection during periods of poor diabetic control and increased glucose concentration. ${ }^{(1)}$ This finding come in agreement with that of Witton et al. ${ }^{(28)}$, Hugoson et al. ${ }^{(29)}$, Khalil ${ }^{(1)}$, Khamrco et al. ${ }^{(35)}$

The third prevalent disease was allergy (42 patients), this was attributed to that histamine levels in chronically inflamed gingiva are higher than levels in normal gingiva, in addition to increase venule dilatation and permeability ${ }^{(30,31)}$, or it may be attributed to that allergy increases in this generation and it may increase more in the future due to exposure to multiple antigenic factors ${ }^{(7)}$.

Blood diseases especially anemia were seen more in the first age group (15-34 year). Anemia may results from iron deficiency, decreased production of red blood cells $(\mathrm{RBC})$, or increase rate of destruction of circulated $\mathrm{RBC}$ resulting in reduction in the oxygen carrying capacity of the blood ${ }^{(32)}$. Also it could be due to improper and unequal food supplement due to economic sanctions imposed on our country.

The tooth type which was mainly extracted more than others was the lower first molar and upper first molar. This was due to the earlier eruption of these teeth ( $6-8$ year), so that caries started early during the mixed dentition period and neglected by the child and his parents, especially in children who don't use tooth brushing or other caries preventive measures, and when the patient reaches adulthood or later without checking their teeth, the teeth already distracted and indicated for extraction. In addition the lower first molar carried the main burden of mastication for a considerable period and the action of gravity contributed materially to the amount of food stagnation it had endure. Nlso it was observed that the number of extracted molars in general was more than other fecth, this may be due to the fact that surface anatomy of the molars and the position of these teeth make them difficult to be cleaned rendering them more liable to be decayed than other teeth $(7,33)$

Upper lirst premolars also showed high number of extractions, about one fourth ( 75 tecth) of extraction of these teeth was clue to orthodontic causes. The other causes like caries, periapical lesion, malposition also have been seen related to upper premolars more than the lower premolar, and this explain the high percentage of tooth loss of upper more than lower first premolars. This was also recorded by Jackson ${ }^{(16)}$, Lundquist ${ }^{(2)}$, Ekanayaka ${ }^{(14)}$, Cahen et al. ${ }^{(12)}$, Khalil ${ }^{(1)}$, and Zaidan ${ }^{(7)}$

Regarding the aetiology of tooth extraction, pulpitis showed the highest percentage $(34.65 \%)$. This finding was also been recorded by Allen ${ }^{(11)}$, Zaidan ${ }^{(7)}$ The reason for this may be due to the low fluoride content of the water supply, in addition to neglected oral health and tooth brushing or cleaning methods resulting in poor oral hygiene and more susecptibility to dental cartes (1)

Periodontal diseases represented the second common cause of tooth extraction $(28.44 \%)$. Periodontal disease has been known as the "disease of neglect", neglecting oral health will allow for occurrence and progression of gingival and periodontal disease leading to tooth loss ${ }^{(34)}$ 


\section{CONCLUSIONS}

- The dentist should interview his or (her) patients carefully to protect them from any complications during tooth extraction.

- Patients should be motivated to seek dental treatment and should be encouraged for regular visits to the dentist.

- Preventive programs should be initiated like water fluoridation and the use of fluoridated toothpaste, dental education programs to minimize tooth loss particularly in young age group.

\section{REFERENCES}

1. Khalil AJ. Loss of permanent teeth. A clinical study of causes of tooth loss in Baghdad city population. MSc thesis, College of Dentistry, University of Baghdad. 1991.

2. Lundqvist C. Tooth mortality in Sweden: A statistical survey of tooth loss in Swedish population. Acta Odontol Scand. 1967; 25: 289 - 321.

3. Ali MG, Al-Salman TH, and Zakaria NA. The oral and dental health status among people in Sharkhan village. Al-Rafidain Dent J. 2001; 2: 166-173.

4. Löe H, Anerad A, Boysen H, Smith M. The natural history of periodontal disease in man. Tooth mortality rates before 40 years of age. J Periodont Res. 1978; 13 : $563-572$.

5. Guralnick WC. Textbook of Oral Surgery. $1^{\text {st }}$ Edn. Churchill Ltd. 1968; Pp: 9-19.

6. Little JW, Falace DA, Miller CS, Rhodus NL. Dental Management of the Medically Compromised Patient. CV Mosby Co. 1997; Pp: 79-102.

7. Zaidan HA. Clinical study and evaluation of healthy and medically compromised patients requiring exodontia. Iraqi Dent J. 1995; 17: 41-48.

8. Thoma KH. Oral Surgery, $4^{\text {th }}$ Edn, CV Mosby Co. 1963; Pp: 290-327.

9. Kruger GO. Textbook of Oral and Maxillofacial Surgery, $5^{\text {th }}$ Edn. CV Mosby Co. 1979; Pp: 36-48.

10. Laskin DM. Oral and Mxillofacial Surgery. CV Mosby Co. 1985; Pp: 23-48.

11. Allen EF. Statistical study of primary causes of extraction. J Dent Res. 1944; 23 : 453.

12. Cahen PM, Frank RM, Tarlot JC. Survey of the reasons for dental extractions in France. J Dent Res. 1985; 64: 1087-1092.

13. Gjermo P, Beldi MI, Bellini HT, Martins CR. Study of tooth loss in an adolescent Brazilian populations. Community Dent Oral Epidemiol. 1983; 11: 371-374.

14. Ekanayaka A. Tooth mortality in plantation workers and residents in Sri Lanka. Community Dent Oral Epidemiol. 1984; 12: 128-135.

15. Manj F, Fejerskov O, Baelum V. Pattern of dental caries in an adult rural population. Caries Res, 1989; 23: 55-62.

16. Jackson D. The mortality of permanent teeth. Br Dent J. 1965; 16: 158-162. 17. Sheiham A, Hobdell MH, Cowell CR. Patterns of tooth loss in British population.
Br Dent J. 1969; 18: 255-260.

18. Krogh HW. Permanent tooth mortality: A clinical study of cause of loss. J Am Dent Assoc. 1958; 57: 670-675.

19. Barclay JK. A survey of dental extraction in New Zealand. II Reasons for tooth loss. NZ Dent J. 1974; 70: 25-38. 20. Roder DM. Tooth loss in south Asutralia. Community Dent Oral Epidemiol. 1975;
3: $283-287$. 
21. Mathur MV, Nath S. Tooth mortality: An analysis of extraction cases. J Ind Dent Assoc. 1968; 40: 213-215.

22. Robert LC, Richmond VA. A comparison of cardiac rate - pressure product and pressure rate quotient with Holter monitoring in patients with hypertension and cardiovascular disease. Oral Surg Oral Med Oral Pathol. 1997; 84: 125-128.

23. Stahl SS, Fox LM. Histologic changes of the oral mucosa associated with certain chronic disease. Oral Surg Oral Med Oral Pathol. 1953; 6: 339-344.

24. Quart A., Sorrin S. Gingival changes observed in arteriosclerotic men. Oral Surg Oral Med Oral Pathol. 1960; 13: 1181-1190.

25. Summers CJ, Oberman A. Association of oral disease with 12 selected variables: 1-Periodontal disease. J Dent Res. 1968; 47: 457-462.

26. Perlstein MI, Bissada NF. Influence of obesity and hypertension on the severity of periodontitis in rats. J Dent Res. 1976; 55: 72-73. (Abstract).

27. Castelli WA, Perzi D, Nasjleti CE, Caffesse RG. Effect of renovascular hypertension on the morphology of oral blood vessels. Oral Surg Oral Med Oral Pathol. 1978; 46: 576-582.

28. Wilton JMA, Griffiths GS, Curtis MA, Madien MFJ, Gillett IR, Wilson DT, Sterne JAC, Johnson NW. Detection of high risk groups and individual for periodontal disease. J Clin Periodontol. 1988; 15: 339-346.

29. Hugoson A, Thorstensson H, Falk H, Kuylenstierna J. Periodontal condition in insulin dependent diabetics. J Clin Periodontol. 1989; 16: 215-223.

30. Nisengard R. The role of immunology in periodontal disease. J Periodontol. 1977; 48: $505-513$.

31. Nisengard R, Newman MG. The host response in periodontal disease. In: Carranza FA Jr (Ed). Clickman's Clinical Periodontology, $6^{\text {th }}$ Edn. WB Saunders Co. 1984; Pp: $343-360$.

32. Little JW, Falace DA. Dental Management of the Medically Compromised Patient. $2^{\text {1d }}$ Edn. CV Mosby Co. 1984; Pp: 260-270.

33. Al-Nori AH. Developmental anomalies of teeth and oral soft tissues among 14-15 years old school children in Baghdad city with special reference to enamel defects. MSc thesis, College of Dentistry, University of Baghdad. 1990.

34. Greene JC, Suomi JD. Epidemiology and public health aspects of caries and periodontal disease. $J$ Dent Res. 1977; 56: 20-25.

35. Khamrco TY, Al-Sayagh GhDh, Makani LA. Association between root surface caries occurrence and systemic diseases in adult and elderly population in Mosul City, Iraq. Al-Rafidain Dent J. 2002; 2 (2): 220-225. 